\title{
Repercussions of COVID-19 on the Ecuadorian tax system and its ranking compared to other countries
}

\section{Repercusiones del COVID-19 en el sistema tributario del Ecuador y su ranking frente a otros países}

ROQUE-VALAREZO, Pamela Elizabeth†**, YUMBO-GUZMÁN, María de los Ángeles and ORELLANA, Milca

Universidad Técnica de Machala, Machala - El Oro - Ecuador.

ID $1^{\text {st }}$ Author: Pamela Elizabeth, Roque-Valarezo / ORC ID: 0000-0001-7653-1869

ID $1^{\text {st }}$ Co-author: María de los Ángeles, Yumbo-Gúzman / ORC ID: 0000-0001-5748-215X

ID $2^{\text {nd }}$ Co-author: Milca, Orellana / ORC ID: 0000-0001-5952-5766

DOI: $10.35429 / J F E .2021 .9 .5 .12 .20$

Received July 15, 2021; Accepted December 30, 2021

\begin{abstract}
Tax systems are essential for the collection of taxes, since the economic spending of the countries depends on them; Among the items we have the Income Tax (IR) and the Value Added Tax (VAT), which are the highest income obligations that Ecuador has. This article aims to analyze the repercussions caused by the COVID-19 pandemic in the collection systems of Ecuador compared to the countries of Latin America. For this purpose, a descriptive-documentary cross-sectional methodology was carried out in order to obtain true, reliable information from indexed databases that were verified and approved by different researchers. The results show that COVID-19 had a direct impact on the economies of Latin American countries, especially in the first half of 2020, however, the policies adopted by governments, precisely in Ecuador, helped reduce the burden of the crisis, by deferring the payment of taxes, which generated momentary relief for local companies.
\end{abstract}

Tax regime, Collection system, Taxes, VAT, Ranking

\begin{abstract}
Resumen
Los sistemas tributarios son fundamentales para la recaudación de los impuestos, ya que, de estos depende el gasto económico de los países; entre los rubros tenemos el Impuesto a la Renta (IR) y el Impuesto al Valor Agregado (IVA), que son las obligaciones de mayor ingreso que posee el Ecuador. El presente artículo tiene como objetivo analizar las repercusiones ocasionadas por la pandemia de COVID-19 en los sistemas de recaudación del Ecuador frente a los países de América Latina. Para el efecto, se realizó una metodología de corte transversal, de tipo descriptiva-documental con la finalidad de obtener información verídica, confiable, proveniente de bases de datos indexadas que fueron verificadas y aprobadas por distintos investigadores. Los resultados demuestran que el COVID-19 tuvo un impacto directo sobre las economías de los países de América Latina, especialmente en el primer semestre del año 2020, sin embargo, las políticas adoptadas por los gobiernos, precisamente en Ecuador ayudaron a disminuir la carga de la crisis, mediante el aplazamiento del pago de impuestos, lo que generó alivio momentáneo para las empresas locales.
\end{abstract}

Régimen tributario, Sistema de recaudación, Impuestos, IVA, Ranking

Citation: ROQUE-VALAREZO, Pamela Elizabeth, YUMBO-GUZMÁN, María de los Ángeles and ORELLANA, Milca. Repercussions of COVID-19 on the Ecuadorian tax system and its ranking compared to other countries. RINOE JournalFinancial Economy. 2021. 5-9:12-20.

\footnotetext{
* Correspondence to Author (Email: proque1@utmachala.edu.ec)

$\dagger$ Researcher contributing first author.
} 


\section{Introduction}

Worldwide, the figure of collection arises mainly on companies, adopted by Western European countries, later the figure of VAT (Value Added Tax) in Latin America is configured that arises in the middle of the 20th century as a compensation measure proclaimed in the Washington consensus, with the aim of being able to recover the lost revenue from world trade taxes. The first country in South America to implement this tax system was Brazil.According to Huamán (2018), there were modifications in the economic structures of governments that implied a tax on basic necessities with the intention of redistributing income in a better way.

Jiménez and Ruelas (2018), affirm that the economies of Latin America show deficiencies in the control and management of their tax systems, since decentralization has made the autonomous governments responsible, which implied more state spending, however, the Lack of strengthening collection policies and efficiency in local administrations have caused a low capacity to generate autonomous sources of income.

In this context, the South American countries according to data from ECLAC (Economic Commission for Latin America), the autonomous governments of the countries of Bolivia, Brazil and Colombia manage to collect through their local governments $10 \%$ of the income that they contribute to GDP ( Gross Domestic Product), however, in the case of Ecuador, the level of collection represents the $5 \%$ that contributes to GDP, in the case of Uruguay the collection represents $3 \%$ of GDP, this shows a low level of participation of the local economies in income for the states (Gómez and Morán, 2016).

The Ecuadorian tax apparatus is configured from the creation of the governing body called the Internal Revenue Service (SRI), with the mission of controlling the State collection system.
With the boom in raw materials, mainly bananas and oil, the level of income in the country increased, however, in the crises of the 90s, Ecuador experienced a time of strong financial crisis, with continuous reforms in tax matters, no it is until 2007 that the tax institution stabilized, maximizing its management, which generated greater income thanks to the control of fiscal policies for tax evasion (Rivera et al., 2019).

For Ecuador, revenue from collection is the main source of sustainability for the general state budget, the authors Quinde et al. (2020), for this there are two forms of collection, the first one deals with the income taxes of the taxpayers that taxes the income and is a direct tax, the second tax of the taxpayers is VAT. According to Calle et al. (2017), tells us that VAT is the one that taxes a value on the part of a transfer, that is, when marketing a good, product or service, it obtains a percentage of its value.

This article seeks to make a statistical comparison of the repercussions of COVID-19 in terms of the collection of taxes for compliance with public policies of the countries. For this reason, the main objective of the research is to analyze the incidence of COVID-19 in the tax collection of Ecuador, through the statistical comparison of collection of the year 2020 in relation to the other countries of Latin America. The study of general concepts such as the tax collected by the country, the added value, and the percentages that Ecuador uses in contrast, such as the tax systems of Peru and Panama, to evaluate the importance of the collection of taxes and the position in which it is located worldwide The structure of this study includes in its first section a documentary analysis of the main theoretical functions and research indicators. In the second section we find the methodology that is characterized by being descriptive, nonexperimental, taking into account the deductive analysis of secondary information. The third section presents the research findings, finally we find the respective conclusions. 


\section{Development}

\section{Taxes that Ecuador collects}

The country annually distributes the resources obtained through the General State Budget (PGE), fulfilling its main objective, which must be equitable for all the cities of the country, as stated by Egas et al. (2019), in Ecuador there are two taxes that are very important since it depends on them to pay for the expenses that each city needs, these so-called main taxes are classified as direct and indirect.

For Carrillo et al., (2019), clarifies that taxes are divided into three parts; firstly, internal taxes, which are those that are composed or are sub-classified into income tax (IR), value added tax (VAT) and special contributions tax (ICE); followed by imports where the VAT and ICE intervene and finally the solidarity Contributions which are those made up of the $2 \%$ VAT, the solidarity contribution of profits and other various taxes.

\section{Tax types}

According to Chávez et al., (2020), mentions two types of taxes based on current Ecuadorian legislation, the authors describe as direct and indirect taxes those items that are part of the responsibility of taxpayers and which cannot be assumed by third parties among the which we found.

\section{Direct taxes}

Income Tax, according to articles 1 and 2 of the law of internal tax regime in, we find that it is considered a type of global income item, which is applied directly to individuals, legal entities and local or foreign undivided inheritance, It is calculated from the income derived from commercial activities, subtracting costs, expenses, deductions.

Single Income Tax, is applied to the banana sector that cultivates, produces and sells nationally or abroad, in accordance with the provisions of the Environmental Promotion and Income Optimization Law corresponding to the State, it is based on calculating $2 \%$ on total gross sales (Garzón et al., 2018).
Tax on motorized vehicles, is paid annually, and consists of an appraisal of the taxable base of the vehicle as established on the SRI page as a regulatory entity and as indicated by the Tax Administration, the payment base that goes from the rate from $0.5 \%$ to $6 \%$ except for public companies. Tax on rural lands, is given for those lands that have more than 70 hectares and are in rural sectors, which implies according to the production code that one per thousand of the basic fraction not taxed for each hectare, complying with the regulations of being greater than the 70 hectares mentioned above (Mejía et al., 2019).

Mining tax the contribution received to the State for this item represents $5 \%$ based on sales, in the case of gold and copper extraction activities, the contribution is $8 \%$ extra to income tax, it is contemplated a payment of $4 \%$ for mining companies that practice this activity on a medium scale, in addition, the tax laws in articles $18,24,40$ and 92 , contemplate $3 \%$ of the collection of this income for the parish governments, with the In order to redistribute income, promoting community development actions in which mining is practiced (Zanzzi et al., 2016).

\section{Indirect taxes}

Value Added Tax, is characterized by being regressive, according to article 52 of the law of internal tax regime, it mentions that this item is taxed in the commercialization phase on transactions and imports, in goods of corporal domain and provision of services, currently The collection rate is $12 \%$, in products corresponding to the basic family basket VAT represents $0 \%$, the income derived from this tax is directed to the accounts of the General State Budget, which is redistributed to the local autonomous governments for financing of public works (Barrera, 2017). Tax on special consumptions, as stipulated in article 82 of the tax regime law, this tax is aimed at collecting on those goods, whether local or foreign, the taxpayers obliged to pay this tax are natural persons, companies that carry out import, manufacturing and franchising operations. 


\section{The Value Added Tax (VAT)}

In accordance with the Organic Law of Tax Regime in its article 52, it clearly establishes the purpose of VAT, "which taxes the value of the transfer of ownership or the importation of personal property of a corporal nature, in all its stages of commercialization, as well as as well as copyright, industrial property and related rights; and the value of the services provided, in the manner and under the conditions provided by this Law".

Given its comparative advantage in the tax structure of various countries, the value added tax (VAT) is very important in any tax reform. In most Latin American countries, an important part of the policy has repeatedly proposed differential tax rates for certain goods and services that make up the basic consumption basket (Vallejo, 2017). Some distributive impact studies also support this theory, pointing out that when the welfare indicator is consumption, the value added tax will have a certain degree of progress. This is due to the positive effects of the tax exemption and the lowering of the value added tax rate. For certain consumer goods, on the contrary, for collection purposes, the IMF proposes to extend the value added tax at a single rate, abolish tax-free goods and lower the tax rate (Garriga, 2021).

\section{VAT declaration and contribution}

From the position indicated by the SRI (2021), the VAT analysis is of vital importance in terms of collection, because it has become the main source of income for the State, this tax is one of those that make their return with more established frequency (monthly or semi-annual) since it generates greater tax obligations, that is why the regulating and controlling entity in charge of collecting emphasizes the importance and concern for those processes that facilitate compliance with tax returns and payments ( Izquieta and Vaca, 2015).

The tax system is structured according to the taxes, which support the indirect sources of income of the States, for this reason, the contribution has been significant at a gradual level, depending on the collection capacity and the application of tax policies, the contribution This item helps to keep the government budget stable (Ramírez, 2013).
From the point of view of Cuestas and Góngora (2014) another reason that leads us to consider the value added tax as an option is when we evaluate neutrality in its terms, because it is a choice that does not change between labor and capital. Neutral taxation, choice and consumer choice between different resource allocations. That is why the emphasis on tax neutrality will depend on its design, which reinforces the idea that broad-based taxes are superior to those that may have exceptions or reduced tax rates. The neutrality of VAT is not quite correct, if you compare it with direct taxes, you can treat it as neutral.

\section{Type of Taxpayers}

As Rivera et al. (2019) tells us that the tax administration in Ecuador for an efficient development in the collection of the Value Added Tax (VAT), classifies taxpayers into two types:

- Natural Persons (obliged and not obliged to keep accounts).

- $\quad$ Companies (public and private for-profit and non-profit companies).

It should be emphasized that non-profit organizations that belong to the Popular and Solidarity Economy sector and are those that receive benefits in the tax area according to the legal measures established by the State and are executed and supervised by the regulatory entity of Internal Revenue Services (SRI), which considers deductions, exemptions and rebates in order to determine the tax to be paid.

\section{VAT in Latin America}

As stated by Lustig (2017) in Latin America, it has been developing important changes in levels and structures since the early nineties, this is attributed some more educated facts that were part of this transformation, while this continuous increase of the average tax burden within the continent shows a certain regularity, but in the same way hides a certain difference between countries. 
It should be emphasized that the tax structure in Latin America shows several common features that contrast vigorously with developed countries, it is essential to consider the magnitude and impact of these comparisons, since identifying those areas where the incorporation of superior tax reforms is necessary.

\section{Methodology}

This research is cross-sectional, based on the study periods 2019-2020, it is also descriptive, and at the same time documentary, due to the innumerable interpretative analyzes through the search for literary sources validated by other authors. According to what was expressed by Ruz et al. (2020), this type of research is subdivided into three aspects, which are supported by documentary sources, applying in this way to bibliographic research that consists of the consultation of books and the hemerographic that is based on the investigation of articles or journal essays.

For the bibliographic review, articles recovered from indexed scientific databases such as Redalyc, Scielo, Dialnet, Scopus, as well as data from government digital platforms such as the Internal Revenue Service, Central Bank of Ecuador, Cepal, among others; with the selection of search criteria such as taxes, collection systems, tax regime, collection in Latin America, Effects of COVID-19 in economies, to carry out the process of deductive analysis of the information recovered.

\section{Results}

With the recovery of tax information retrieved from the portal of the Internal Revenue Services (SRI), Inter-American Development Bank (IDB), Association of Banks of Ecuador (ASOBANCA). The data analyzed correspond to the study period 2019-2020, through the presentation of statistical tables and graphics, which allow identifying the level of collection of Ecuador in times of pandemic, compared to other countries.

\begin{tabular}{|l|r|}
\multicolumn{1}{|c|}{ Direct taxes } & $4.406,761$ \\
\hline Income tax & 677 \\
\hline Other direct taxes & 964,093 \\
\hline Foreign currency outflow tax & $\mathbf{5 . 3 7 1 , 5 3 1}$ \\
\hline Total & \\
\hline Indirect taxes & $4.093,133$ \\
\hline Internal VAT & $1.413,120$ \\
\hline VAT imports & 578,889 \\
\hline Special consumption tax & 169 \\
\hline Other indirect taxes & $\mathbf{6 . 0 8 5 , 3 1 1}$ \\
\hline Total &
\end{tabular}

Table 1 Tax collection regarding direct and indirect taxes, 2020 period

Source: Asociación de bancos del Ecuador (2020)

Ecuador has two important sources of income that contribute to GDP, for the year 2020 direct collections where the Income Tax (IR) is one of the largest collectors, together with other types of taxes amounted to $\$ 5,371,531$ millions of dollars; In the same way, indirect items such as Value Added Tax (VAT) represented a total of 6,085.311 million dollars for the year 2020 .

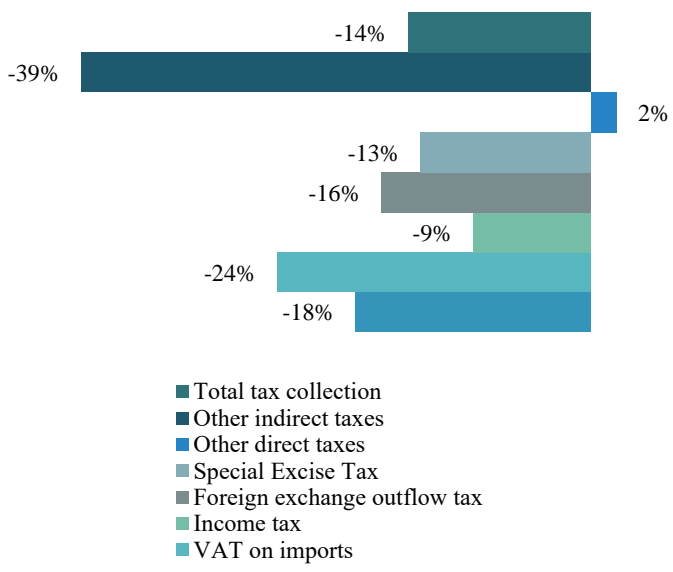

Graphic 1 Variation of the main taxes in Ecuador period 2020 in relation to the year 2019

Source: Asociación de bancos del Ecuador, (2020)

During the first semester of 2020, Ecuador showed decreasing collection figures, in total, collection was reduced by $14 \%$ compared to 2019; The values collected were on average $\$ 10,761$ million dollars, with a loss of around 1,752 million in income, in contrast to the 2019 period, basically the income tax reduced its taxation by $9 \%$ compared to 2019 , that is, 4,106 million were collected. The value added tax also suffered a considerable impact, reaching 3.69 billion dollars, unlike in 2019 , the collection decreased by $21 \%$. 


\begin{tabular}{|l|c|c|r|}
\hline Tax & $\mathbf{2 0 1 9}$ & $\mathbf{2 0 2 0}$ & \multicolumn{1}{c|}{ Variation } \\
\hline $\begin{array}{l}\text { Collection of internal } \\
\text { VAT }\end{array}$ & 4.489 & $3.690,4$ & $-17.80 \%$ \\
\hline $\begin{array}{l}\text { VAT collection on } \\
\text { imports }\end{array}$ & $1.668,3$ & $1.265,5$ & $-24.10 \%$ \\
\hline Income tax collection & $4.495,3$ & $4.106,4$ & $-8.70 \%$ \\
\hline
\end{tabular}

Table 2 Evolution of direct and indirect tax collection in Ecuador

Source: Asociación de bancos del Ecuador, (2020)

The contribution of VAT to the General State Budget is very significant, the comparison between the last two fiscal periods, expresses that for the year 2019 both the internal VAT and imports collected 4,489 and 1,668.3 million respectively, however, in the year by 2020 these items accounted for 3,690 and 1,265.5 million of the previously detailed taxes, which shows that there was a negative variation of $17 \%$ in internal VAT and $24 \%$ in VAT on imports.

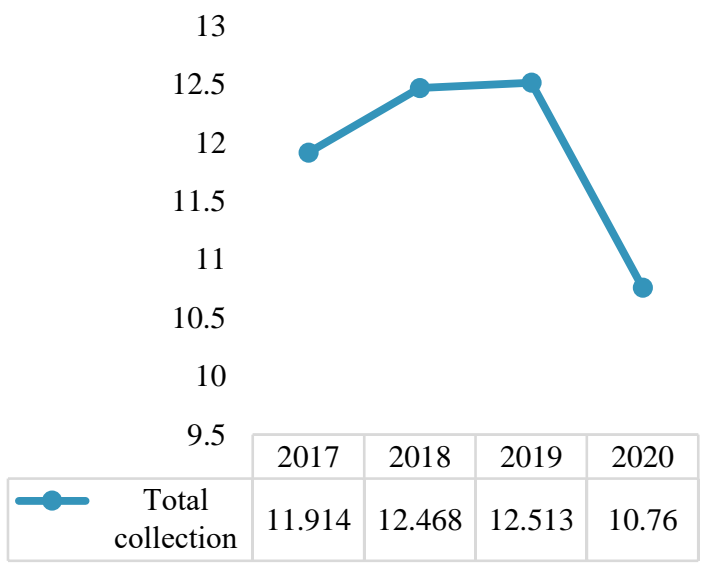

Graphic 2 Variation in collection behavior in Ecuador Source: Asociación de bancos del Ecuador, (2020)

At the global collection level, Ecuador within the 2017 to 2019 periods has maintained a constant collection curve, however, for the 2020 period, as illustrated in graph 1, there is evidence of a drop in tax collection, due to different factors. market externalities, such as the declaration of the global COVID-19 pandemic, which represented significant losses in the level of collection for international economies.

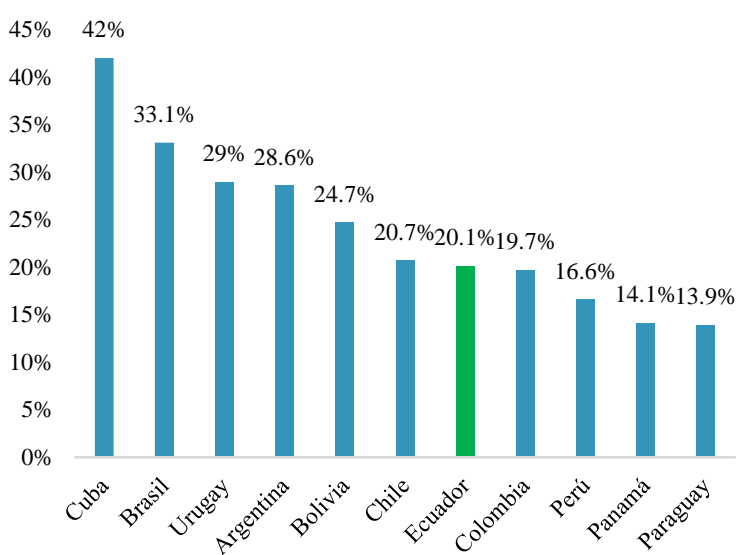

Graphic 3 Ranking of tax collection in Latin America for the 2020 period

Source: Banco Interamericano de Desarrollo, (2021)

The ranking of the economies of South America, studied in the period 2019, based on the repercussions of the health crisis, graph 2 shows that Ecuador in level of tax collection contributing to the Gross Domestic Product (GDP), in relation to the different countries, show that Ecuador stands at $20.1 \%$ for 2019 , decreasing 6 percentage points compared to 2018, and at the level of Latin American and Caribbean countries it was below the regional average, which is $23 \%$.

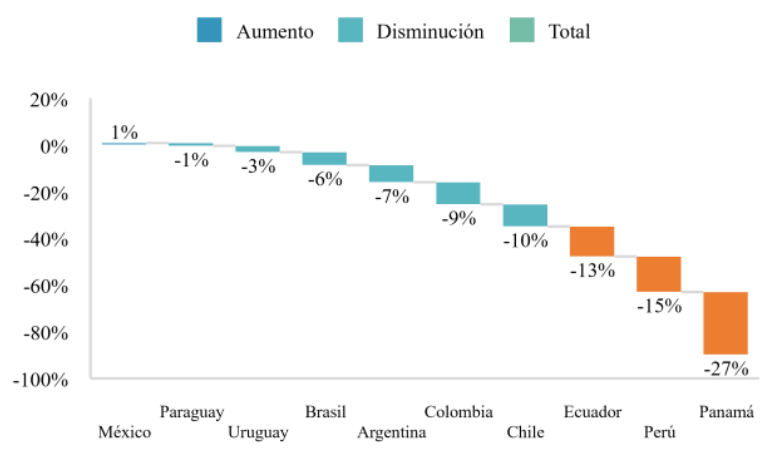

Graphic 4 Percentage ranking of the level of tax collection in Latin America for the 2020 period Source: Banco interamericano de desarrollo, (2021)

The collection history of the Latin American countries, according to graph 4 shows a sharp drop in the collection systems for the year 2020, based on the income tax (IR) the decrease at the regional level is around $8.2 \%$ and in the value added tax (VAT) the reduction is around $7.8 \%$, as evidenced by a greater impact on income from income; In global calculations we see that Mexico has an increase of only $1 \%$ in relation to the year 2019, however, Ecuador presents a collection loss of $15 \%$ compared to the previous year, in the same way Panama is the country that has the most repercussions on tax revenues presents with $27 \%$.

ROQUE-VALAREZO, Pamela Elizabeth, YUMBO-GUZMÁN, María de los Ángeles and ORELLANA, Milca. Repercussions of COVID-19 on the Ecuadorian tax system and its ranking compared to other countries. RINOE Journal-Financial Economy. 2021 
Effects of COVID-19 on the economies of Latin America

At the end of 2019, tax revenues increased slightly in Latin American countries, the items that contribute to GDP, presented an average of $13 \%$, with Cuba showing the most growth of $42 \%$ due to its main source of income, which is tourism, in the case of Ecuador income bordered a $20 \%$ contribution to GDP.

However, at the beginning of 2020, the economies of around 18 Latin American countries, including Ecuador, experienced significant average losses of approximately $11.2 \%$ in tax revenues compared to the period 2019 , the global declaration of the health crisis, forced to the world economy to adopt adjustment policies to give relief to the markets by cushioning the tax burden and providing momentary compensation measures to gradually recover the commercial sector.

In the middle of the 2020 period, there is a slight recovery in the collection systems, due to public policies to protect companies, social assistance programs, credit bonds, freezing of deadlines for the payment of taxes and alternative adjustment measures for the periodic payment of tax contributions. In addition, one of the main items of the countries, in the case of Ecuador, oil decreased, due to the fall in international prices, aggravating the crisis as a result of the measures adopted by the Ecuadorian government, which momentarily paralyzed the payment of the tax on income in the different business sectors and productive industries.

One of the main income items in Latin American countries is the value added tax or sales tax, this item had negative repercussions throughout the region, for the first period of 2020 , specifically in the month of May. It is where the largest drop in this tax is recorded with $29.5 \%$ in relation to previous records, subsequently, a slight recovery is shown, however, the figures continue to be negative in the months of June (17.2\%), July (14.4\%), August (2.5\%), September (3.9\%) and December $(9.1 \%)$, this shows that the measures adopted by the countries allowed the economy to adjust, minimizing the effect of the health crisis, however, although the negative figures have The diminished impact is still reflected in a global economic slowdown.
In total terms, the average tax decrease in the region stands at $11.7 \%$, for the second semester of 2020, an improvement in income is perceived that is sustained, due to the lifting of certain restrictions in aspects of capacity of public spaces, mobility, reopening of certain business sectors, to reduce the implications of the pandemic. Despite the negative percentages in collection, a slight improvement is evident, even maintaining decreasing values, from this point of view, the countries that show the greatest slowdown are Panama (35\%), Honduras (19.5\%), Ecuador (17.3\%), Jamaica (17.2\%), in contrast, there were economies that showed recovery from the second semester of 2020, such as Paraguay (2.4\%) and Mexico (2.3\%).

\section{Conclusions}

It can be concluded through the investigative findings that the variable COVID-19 has had a significant impact on the collection systems, markets and economies of all Latin American countries, particularly in Ecuador, the effects of the pandemic caused losses in collection matters of approximately $15 \%$ for the first semester of the year 2020 in relation to the year 2019.

According to the statistical results of the study, it is concluded that the countries were affected by their local economies, due to the restrictions established by the World Health Organization (WHO); The internal policies applied in each State helped to reduce the indexes of negative collection figures, managing to present slightly better values in the subsequent months of the first semester of 2020.

It is concluded that it is necessary for Ecuador to articulate economic recovery policies from the COVID-19 crises, which still latently continues to impact business markets, public policies will be key to guarantee a reconstruction of social and productive level, through the establishment of reactivation provisions with the granting of bank credits, channeled tax policies and control of public spending that allow for sustainability and growth of the economies.

This study was aimed at analyzing the implications of COVID-19 in the tax system of Ecuador compared to the other countries of Latin America, however, for future lines of research it could be convenient to analyze the different public policies on tax matters and their recovery impact in local businesses. 


\section{References}

ASOBANCA. (2020), Boletín macroeconómico. https://www.asobanca.org.ec/file/2972/downloa d?token=glKKiFeh

Barrera, C. B. (2017). El IVA en el Ecuador: un impuesto acumulativo. Imprenta Digital de la Universidad del Azuay. http://publicaciones.uazuay.edu.ec/index.php/ce uazuay/catalog/view/46/43/470-1

Banco Interamericano de Desarrollo. (2021). Banco Interamericano de Desarrollo. https://oe.cd/RevStatsLatam

Calle, O. R., Malla, A. F., Lalangui, L. M., y Guamán, G. F. (2017). El impuesto al valor agregado IVA en Ecuador y su incidencia en las recaudaciones tributarias. Revista Sur Academia, 4(7),

87-94.

https://revistas.unl.edu.ec/index.php/suracademi a/article/view/482/381

Carrillo, P. W., Sánchez, C. P., y Carrillo, P. G. (2019). Recaudación de impuestos por domicilio fiscal Ecuador: zona de planificación tres (Chimborazo, Cotopaxi, Tungurahua, Pastaza), 2007-2018. Boletín de Coyuntura (21), 22-26. doi:http://dx.doi.org/10.31164/bcoyu.21.2019.6 93

Chávez, C. G., Chavez, C. R., y Betancourt, G. V. (2020). Análisis de la contribución del IVA, Renta, RISE e ICE en la zona 7 del Ecuador período 2013-2017. Universidad y Sociedad, 12(2), 330-335. http://scielo.sld.cu/scielo.php?script=sci_abstra ct\&pid=S2218-

$36202020000200330 \& \operatorname{lng}=e s \& n r m=i s o$

Cuestas, C. J., y Góngora, A. S. (2014). Análisis Crítico de la Recaudación y Composición Tributaria en Ecuador 2007-2012. Revista Politécnica, 34(1), 1-10. https://revistapolitecnica.epn.edu.ec/ojs2/index. php/revista_politecnica2/article/view/303

Egas, M. F., Cifuentes, L. M., Preciado, D. T., y Esther, A. P. (2019). El impuesto a los consumos especiales (ICE) aplicado a las bebidas alcohólicas incluida la cerveza. Visionario Digital, 3(2), 294-304. doi:https://doi.org/10.33262/visionariodigital.v $3 \mathrm{i} 2.477$
Garriga, M. (2021). Repensando el impuesto al valor agregado. Estudios económicos, 38(76), 197-222.

https://www.redalyc.org/articulo.oa?id=572365 672007

Garzón, C. M., Radwan, A., y Peñaherrera, M. J. (2018). El sistema tributario y su impacto en la Economía Popular y Solidaria en el Ecuador. Revista UNIANDES Episteme, 5(1), 38-53. https://dialnet.unirioja.es/servlet/articulo?codig $\mathrm{o}=6756345$

Gómez, S. J., y Morán, D. (2016). La situación tributaria en América Latina. Cuadernos de economía, 35(67), 1-37. https://dialnet.unirioja.es/servlet/articulo?codig $\mathrm{o}=5278364$

Huamán, S. M. (2018). Sistema tributario aduanero peruano y beneficios de los acuerdos de integración comercial Perú-México. Lex: Revista de la Facultad de Derecho y Ciencia Política de la Universidad Alas Peruanas, 16(22), 271-300. https://dialnet.unirioja.es/servlet/articulo?codig $\mathrm{o}=6760583$

Izquieta, P. L., y Vaca, L. G. (2015). Impuesto al Valor Agregado (IVA): Evolución, tarifas y aportes de las principales ciudades: Caso Ecuador. Revista FENopina(70), 1-5. $\mathrm{http}: / / \mathrm{www}$. revistas.espol.edu.ec/index.php/fen opina/article/view/62/77

Jiménez, J. P., y Ruelas, Á. I. (2018). Autonomía tributaria subnacional en América Latina. Documentos de trabajo (FEDEA)(10), 1-24. https://dialnet.unirioja.es/servlet/articulo?codig $\mathrm{o}=6525559$

Lustig, N. (2017). El impacto del sistema tributario y el gasto social en la distribución del ingreso y la pobreza en América Latina. El trimestre económico(335), 493-568. https://dialnet.unirioja.es/servlet/articulo?codig $\mathrm{o}=6451422$

Mejía, F. O., Pino, J. R., y Parrales, C. C. (2019). Políticas tributarias y la evasión fiscal en la República del Ecuador. Aproximación a un modelo teórico. Revista Venezolana de Gerencia, 24(88), 1-15. https://www.redalyc.org/articulo.oa?id=290620 51010 
Quinde, R. V., Bucaram, L. R., Saldaña, V. M., y Díaz, C. C. (2020). Relación entre los ingresos petroleros y el gasto público ecuatoriano. Revista de ciencias sociales, 26(3), 118-129. https://dialnet.unirioja.es/servlet/articulo?codig $\mathrm{o}=7565471$

Ramírez, C. E. (2013). La Generalización del Impuesto al Valor Agregado: ¿Una opción para México? Revista Mexicana de Ciencias Políticas y Sociales, 58(219), 75-101. http://www.scielo.org.mx/scielo.php?script=sci _arttext\&pid=S0185-19182013000300004

Rivera, K., Narváez, C., Giler, L., y Erazo, J. (2019). Evaluación tributaria de los gastos imputables para la declaración del Impuesto al Valor Agregado IVA en la Asociación de servicios de alimentación, limpieza y mensajería La unión hace la fuerza "ASOUNF". 593 Digital Publisher CEIT, 4(3-1), 59-75. https://dialnet.unirioja.es/servlet/articulo?codig $\mathrm{o}=7144056$

Ruz, F., Molina, P. E., y Contreras, J. M. (2020). Evaluación de conocimientos sobre el contenido de estadística descriptiva de futuros profesores de matemáticas. Avances de investigación en educación matemática (18), 55-71. https://dialnet.unirioja.es/servlet/articulo?codig $\mathrm{o}=7799250$

SRI. (2021). Estadísticas generales de recaudación.

https://www.sri.gob.ec/estadisticas-generalesde-recaudacion-sri

Vallejo, Z. L. (2017). El dilema de la Reforma Tributaria: ¿estructural o fiscalista? Revista Apuntes del CENES, 36(63), 9-10. http://www.redalyc.org/articulo.oa?id=4795531 73001

Zanzzi, F., Cordero, L. A., y Cordero, L. M. (2016). Reformas tributarias modeladas con vectores autorregresivos: Caso Ecuador. Economía, 41(42), 53-75. http://www.redalyc.org/articulo.oa?id=1956500 99003 